\title{
Modern Man's Predicament in the Selected Novels by Naguib Mahfouz
}

\author{
Ali Dakhil Naem¹, Dr. Lajiman Bin Janoory²
}

${ }^{1} \mathrm{Ph}$. D. Student in Literature, Iraqi, Ministry of Education-Iraq alidakhi12016@gmail.com

${ }^{2}$ Faculty of Languages and Communication, University Pendidikan Sultan Idris, Tg. Malim Perak, Malaysia lajiman@fbk.upsi.edu

\begin{abstract}
This study aims at analyzing the selected novels of Naguib Mahfouz in the light of the existential predicament of man. Such predicament is manifested in the aspects of despair, frustration, betrayal and poverty. The study assumes the existentialism as a theory and topic to comment on the situation. This study aims at the following objectives: To analyze a reflection of moral chaos in Naguib Mahfouz's selected novels. To show the modern man's predicament based on the selected novels by Naguib Mahfouz. To explain how existentialism is able to express the predicament of the modern man based on Naguib Mahfouz's selected novels? This study follows the existential theory as an outline onto how the project of the present study will be carried out. It specifically presented the theoretical framework of the study, as well as the related theories and concepts necessary for data collection and interpretation. The study arrives at the conclusion and findings that the moral chaos in Naguib Mahfouz's selected novels of the study are a genuine fact of the aftermath of colonial period in Egypt. Moreover, modern man's predicament is brilliantly portrayed in the characters who are in a constant struggle to journey from their repressed daily affairs into the post-colonial lifestyle. Such shift from traditions to modernity has led to the existential predicament on the account of the modern Egyptian individual and society. The study examines the life of the Egyptian community from the existential perspective; and it is necessary for the Arab countries to consider. The study is open for further research like feminism, gender studies, and the familial relationships.
\end{abstract}

Keywords-predicament, Modern man.

\section{INTRODUCTION}

Most of Naguib Mahfouz' short stories and novels are built on the assumption that man is the main subject of the fiction, hence as a character who represents the modern man during the thick times of agony and suffering. The themes of the predicament are the gist of the works that are written by Mahfouz to display the misery, anguish and the frustration as part of the existential problem that the novelist tries to convey to their readers during the modern era. This paper focuses on the so called existential Predicament of the modern man. The researcher in this chapter will examine how the modern man/Woman is put under a thorough social burdens and hard human conditions; moreover, the researcher would diagnose the reasons that have led them to such a frustrated behavior as well as the tragic fall of each character in the novels that are selected for the discussion.

Naguib Mahfouz is prolific writer who adopted the psychological and the existential perspective to hint out to the consequences of his characters. He drags his readers to the dark side of the human conditions and made the readers feel the pain, the agony and the staggering state of affairs of his characters. The man / woman is put under very devastating and competitive circumstances; they have to fight and struggle to secure a place in a world of delusion a world that is different to their original home and tradition. Thus man is crippled and crushed between the cruel modernity and the lost antiquity that is midway between the Muslim Egyptian traditions and the western colonial trends.

The time of writing the most influential works of Naguib Mahfouz roughly dates with the rising of modernism the huge movement that invaded the art and literature. Hence, the topics that he enriches his approach of writing attribute to the philosophical movement of existentialism. Existentialism as in the works of ElfrideJelinek, Albert Camus, Thomas Bernhard, Kenzaburo, Yukio Mishima, and Jean-Paul Sartre. The search for the self, the meaning behind life and the images of the frustration and anguish that have evaded Europe and the Middle East are all represented in the selected novels for this study.

In the Midaq Alley the novelist has raised the issue of the loose morality that have resulted from the sudden 
arrival of the western trends into the conservative and the Islamic society of Egypt and made it an easy prey in the face of modernism. Thus one can observe an urge for a change in life a way out of the outdated values. Such a search falls in the accounts of the existential philosophy that calls for the meaning of the existence.

While the major work of The Cairo Trilogy which he includes three novels that trace three generations over thirty years' period of time in the life of a traditional Egyptian family. The family is torn fragmented by the effects of the conflicting western trends and the oldfashioned traditions of Egypt.

This family saga is . . roughly covering three generations, the first one from the period before the First World War, the second one immediately after this War and the third one starting almost simultaneously with the beginning of the Second World War. The dominating father symbolizes the older generation with all its certainties, which prove to have been undermined by 1919 . The second generation is depicted as the hesitant transition to the third one, which is characterized as torn between conflicting ideologies of socialism and Muslim activism. (Brugman,1984, p. 301)

Naguib Mahfouz has offered for the theme of the human predicament in the character of Said Mahran the socialist and the thief who undergoes different stages of life and out of the sense of betrayal and frustration loses himself. The existential approach is implemented in the behavior of the thief Said who is disappointed by the nearest people around him wife, daughter, friend and political mentor. In The Thief and the Dogs' context the predicament is personal and it is developed inside the psyche of Said Mahran who believes that revenge is the only means remained for him after he has lost everything in his life like his family, job, and the social courtesy. The novelist in this respect wanted to show the pessimism in the character of Said who assumed the negative ways of living, yet the novelist displays all facets of futility and anarchy of the modern existence, the futile efforts by Said have all Gone with the Wind when his political mentor let him down by giving up the principles of socialism and changes his political views. Moreover, the behavior of his wife who followed another man has also increased his predicament.

Finally, the mid-20th century era has witnessed the emergence of the absurd theatre in due to the development of the existentialism and the ideas of absurdity and the futility of human existence. Mahfouz has contributed to such themes in his novel The Beggar in which the protagonist is in a search of a remedy to his sickness. Throughout the entire novel the novelist sets his protagonist in a constant search for some remedy, in the same way the two characters in Samuel Becket Waiting for
Godot. In his way of searching the major character feels the futility of his action as he loses the faith in the 1952 Egyptian revolution. There is much depression and ennui in the mind of the protagonist of the novella.

The Beggar is a story of the successful, wealthy, wellrespected lawyer Omar, from Cairo, has arrived at a psychological cataclysm in his middle-age. His desperation and search for meaning keeps him loaf from his family his work, and his friends. Omar is a young idealist during the 1930's with eagerness to concede some socialist change; he now fears the sense of irrelevancy more than anything.

\section{THE STATEMENT OF PROBLEM}

After reading most of the body work of the prolific novelist Naguib Mahfouz the researcher has observed a tendency in the behavior of the majority of his protagonists that develops to become a fact. Such behavior represents a problem that is growing in the Egyptian community as part of the Arab world. The tendency to find a better place, leaving the old-fashioned values, and the search of identity due to the changing trends of living in effect of the colonial existence have called upon the problem of the existential predicament that the majority of the characters in the works of Mahfouz undergo.

According to the texts that are selected for this study the main characters pass through a moral crisis that arises to be chaotic as the main character lead an immoral way of living in a society that is supposed to follow the religious discipline, and so are the majority of the characters in the Midaq Alley for example follow the model of Hamida who aspires to cross the boundaries of the Egyptian traditional society. The Cairo Trilogy also provides such examples of loose morality in the behavior of the man of the family who lead a double standards life of domestic discipline and outside indulgence. The other novel the Thief and the Dogs has the crisis of immorality that the characters show as they betray the main character Saeed. Moreover, Omar the main character in The Beggar who shuns the doors on his normal life as a lawyer and poet for the sake of search a remedy to his unknown sickness.

Thus, the researcher has identified these behaviors as increasing problem that affect the Egyptian society in particular. And the interpretation of such mal-functioned way of living is drawn on "the existential basis". The characters in the selected novels are in "predicament" of living in a country that is freed from the colonial powers and the effects of the colonial existence still echo in the society which leads to the crippled and confused behavior of the majority of the characters. Hence this study investigates this problem with the help of the 
"Existentialism" to provide a reasonable justification for the problem of the study and recommend for a successful solution for the standing problem.

\section{THE NIHILISTIC ALLEY IN THE MIDAQ ALLEY}

As part of the nihilistic settings of the novel the Midaq Alley is a miserable and agonized place that everybody of its inhabitants aims to get out, hence such a hard conditioned alley is hated by main characters in the novel. However, Mahfouz starts with introducing Kirsha's cafe, which symbolizes the social center of the alley, and sweeps through several of the ever-present characters within: "Many things combine to show that Midaq Alley is one of the gems of times gone by and that it once shone forth like a flashing star in the history of Cairo ... And then there is its coffee-shop known as Kirsha's. Its walls decorated with multicolored arabesques, now crumbling, give off strong odors from the medicines of olden times, smells which have now become the spices and folk-cures of today and tomorrow..." (Mahfouz, 1947.Midaq Alley.p.1). When the night begins, the men assemble there for drinking tea, smoke, and chat. RadwanHussainy is such brilliant man and the most dedicated one among Midaq Alley's characters. Others see him for spiritual advice in times of conflict and misunderstanding, his religious credibility and wisdom come into play. On the other hand, the owner of the cafe Kirsha, who "had always lived a most irregular life, and he had rolled in its dirt so long that it appeared to him a perfectly normal one" (Mahfouz, 1947.Midaq Alley. p. 39). He shows no shyness and never asks for an atonement or remorse, he would rather persist on the evil deeds "a veil of darkness", and becomes a victim to his perversions. It seems that his morality is not functioning well; hence, he is thrown into a dark place and condition where he sees no way out. In Islam, homosexuality is forbidden and is regarded as one of the biggest sins, Yet, the society of the alley seems to tolerate it like anything else. Mahfouz materializes these wrongful deeds in Kirsha's character. Kirsha engages himself multiple illegal behaviors that are despised and denounced by the society. However, Hussainy tries friendly with him to convince him stop these ill practices by saying, "You know, Mr. Kirsha, I have not brought the matter up to offend you, or to make you feel shame. I just want to offer my advice for whatever good it will do." And he adds, "this boy is immoral and has an evil reputation...I am appealing to you for your own good and the good of your home. Give up this boy; he is just filth created by Satan" (Mahfouz, 1947.Midaq Alley. p 82-83). Kirsha's response is that "he was free to do as he wished and that no one had any authority over him" (Mahfouz, 1947.Midaq Alley.p. 83). Desperately, Husainy nodes his head and says the words from the wholly Qur'an, "You cannot lead aright whomever you wish; it is God who leads whomever He wishes" (Mahfouz, 1947.Midaq Alley. p. 80).

Hussain the son of Kirsha is also another character in the novel he is caught in a plight and he dislike the living conditions the alley and its people. He is another character with the predicament, to stay is to suffer the anguish to move out of the alley is to enter the unknown. He joins the work in the British army, where he gets money, yet the amount he earns does not cover his spending, to balance the things, he doubled his income by selling stolen items. By such behavior of getting illegal cash Hussein struggles in his predicament to survive, eventually he resembles his father, Hussain is undisciplined type of fellow he purchases extravagant food, hashish and liquors, all of these items are not allowed to Muslims. Lane mentions that "this pernicious and degrading custom" is adopted in Egypt before the middle of the thirteenth century". (Lane,1954. p.341) Hussain's motive of leaving the alley is applicable to his childhood friend, Abbas al-Hilu, who also is tempted by fortune to leave his barbershop and find some job with the British. Hussain argues Abbas, "Everyone in this alley is half dead, and if you live here long, you won't need burying" (Mahfouz, 1947.Midaq Alley.p. 31). However, Abbas is a quite gentle and modest man; he does what right only, and saves money his plan to marry Hamida the protagonist. However, his virtue causes his tragic end as he attempts to protect the honor of his fiancé Hamida.

\subsection{The Suffering of the Individuals}

There are two characters in the novel that Mahfouz uses to show the extent of the predicament of the regular people of the alley, in fact these two characters contribute to increasing the suffering of the alley poor inhabitants. Doctor Bushl and Zaita represent the dirt and ugliness, which characterize the Midaq Alley. Zaita instead of changing the conditions of the poor, he worsens the living of people by the act of mutilating them and reduces them to beggars, "... I am the best of people, not the worst, regular beggars don't earn a penny, whereas if I give them a deformity they can earn their weight in gold? It's a man's worth, not his appearance that counts" (Mahfouz, 1947.Midaq Alley. p. 113). Beggars are in patiently waiting to see him; they flock together under cover of darkness to the 'wasteland' where Zaita is, in order to have themselves distorted by his evil art. Such types of people are sons of the world of ignorance, sickness, and poverty. Begging is the only way to survive; their case is a 
metaphor of an entire nation that also survives by culturally begging from the West. However, deformity is necessary for the practice of begging and so are cultural transition requires pain and deformity.

Hamida is the protagonist of the novel represents the moral ambiguity that grows clear, as Hamida grows conscious of her extraordinary beauty, and she shows no compunction about using it. She approves to Abbas's proposal, then changes for another suitor (the old man Salim Alwan who would provide luxury). However, her ambitions of luxurious life are abolished when Salim Alwan gone through heart attack. Later on, Hamida is allured again by a man of high class Ibrahim Farag who abandons her as a whore with no remorse. In the end of the story, she takes advantage of Abbas' sincere love to take revenge from Ibrahim Farag. Abbas accepts to protect her "honor" just as he knows that her honor has been sold and bought many times among the British soldiers. She eased in mind that her fiancé Abbas determines to cancel his plans of marriage, "...what you did will always stand between us..." (Mahfouz, 1947.Midaq Alley.p. 228). However, Hamida does not look like to bewail her misfortunes or contemplate her morality. The worthless death of Abbas makes an impression on the mind of the readers to see him as the representation of villain character by sacrificing his life for Hamida's mistakes. "More significantly, the sexual politics, however, rise to its peak towards the end of the novel, when the enraged drunken soldiers in the tavern fall on Abbas from all sides like "wild animals", killing him with blows, kicks, and glasses fly in all directions, while his friend Hussain is paralyzed and watch impotently" (Mahfouz, 1947.Midaq Alley. p. 241-242).

Midaq Alley manifests its moral ambivalence obviously in the framework of the story, that revolves around a punch of the Midaq Alley's residents in an improvised quarter of Cairo, for them money counts as everything, the morals issues detail professionally with the existential requirements, the events contribute to the main theme of the existential predicament Throughout tensed situation between the life of the alley and the temptation of the modernity. Those who really leave the Alley motivated by working for the British, such a manifestation of modernity leads to one man penniless, another dead, and a woman prostitute. Zaita trudges in the dark alley to see his beggars to get his share of the day work of collection. Hamida engaging with British soldiers, Abbas brawls with British soldiers, Booshy and his friends are to dig up the graves for valuables, the perverted Kirsha following young men, and so on. Gassick asserts that "these universal problems of behavior and morality the novel examines remain the same". (Gassick,1991. p. viii)
Hence, the theme that underlies the collision between modernity and tradition is the only between the social and economic status. Mahfouz personified Midaq Alley as the place of two dissimilar cultures through two domains: the life of the Midaq Alley (the inhabitants) and the world outside the Alley (the Western colonization). Every world has its own traditions and culture that distinguishes it from the other. For example, the Arab woman does not put on revealing or tight cloths publically because it is thoughtout to be shameful and coarse in Arab religion. Thus, it assumes one more phase of predicament of women in particular the Arab who is submissive, passive, and oppressed. On the other hand, Arab societies think about the Western women as lost and immoral. Yet still, in their predicament the Arabs grope for modernization. Mahfouz provides examples of the factory girls and Jewish women as the reflections of the Western tradition and feminist's opinion too, who are in the perspective of Hamida pretty, bold, rich, and knowledgeable; work freely with "a nice clothes." And he employs Hamida as a vivid image of Islamic feminism who later is hooked and sabotaged by the ideological impacts of the Western. Mahfouz through his characters, states that the world of the Midaq Alley is an ultimate description of the less resources, religion, tradition, joys, and moreover, agony of the people of an alley that only offers an earthly existence with glimpse of hope. It "was a place that did not treat its inhabitants fairly" (Mahfouz, 1947.Midaq Alley. p. 32). The world beyond them is reflected in form of temptations of modernism, opportunities employment, secularism, fashion, money, and carefree. Due to the fact power and money could satisfy their lust, the inhabitants of the ally are overwhelmed with such predicament of to go out of the poverty and head to the unknown. Hamida is captivated by Western allurements due to her thirst for richness and authority meanwhile Abbas dies for defending her honor. Diiulio makes it very clear as she announces, "...the reader will realize how not only the characters are entrapped in cages of subservience, but also readers of Mahfouz are trapped in cages of misunderstanding." (Diiulio, 2007.p.xxi) Mahfouz's personas are representation of the poorer layers of the society in it he traces the tragedy and sadness of their lives. Their lives become miserable and unfortunate due to the two conflicting social approaches of thoughts, (modernity and tradition), both tradition and modernity don't solve their problems, rather, they make them more complicated. Giving these features, the readers come to understand that the alley doesn't any redemptive values. The reader realizes throughout the novel the disparity between the tradition and the modernity in Egypt during the 1940s, which stands for the reenactment of the 
East-West encounter and the values, whether aesthetic or moral, that each world displays.

\section{THE RESTRICTED FAMILY INTHE CAIRO TRILOGY}

As part of the human predicament the behavior of the father of the house AlssayyedAbduljawad is so decisive and restricted type of fellow he was. Such familial restrictions have contributed to increase the predicament of the individuals in the novel right from the start. In Palace Walk, the predicament is afflicted to the young boy Kamal who is strongly attached to his mother, Amina, and feels some kind of intensity towards his father. Due to the stiff and rigid manner of the father Kamal finds refuge in his mother who intimately teaches him about Qur'ān, discusses many texts from it, and memorizes his school homework with her. Mahfouz writes, "The boy did not doubt these tales and believed in them, because they came from his mother and they did not conflict with what he learned about religion in school. Moreover, the mentality of his religion teacher, as revealed by his casual remarks, did not differ from his mother's". (Mahfouz,1989. p.64) Kamal was captivated by the legends in a manner that none of his dry lessons could match. Overwhelmed with excitement and dreamy imagination, his mother's lesson was one of the happiest times of the day. Kamal grows a tough and crucial character in the novel as he grows older and his personality is polished due to the circumstances in his family, like the death of his brother Fahmy, that shocks the household and is the turning point to several of the members of the family. In a particular way Kamal is affected, as he had considered Fahmy as a role model who lived free and died for freedom. Kamal is type of man who assesses his life by monitoring and observing his family members, yet he oversteps the limits that have been established by his father, the old generation, and society, for example the behavior of taking his mother to make a visit to the shrine of Al-Husayn, - Kamal helps his mother to go beyond the boundaries of her house, from which she is eventually banished. Through these actions, Kamal is in amidst of predicament that he wants to go against his father and also strict fundamental rules and taboos which he started to have doubts about. He is overwhelmed with fear of his father to the extent that he can scarcely ask him to bring his mother back. Moreover, he was so trembling he was unable to see where he was putting his feet. AlSayyid Ahmad moved to go back into his shop. The moment his father's eyes turned away, the boy relived. Fearing that the man would leave and the chance is gone, without prior thinking to consider what he was saying
Kamal screamed, "Bring back Mama, God help you." Then he sped away as fast as the wind. (Mahfouz,1989. p.217)

Many other things in Mahfouz's novels portrait the suffering of modern man who is encountered with questions of the religious, and secularity. How do characters develop and opens out in his novel Cairo Trilogy and what kinds of changes happen through the association of the younger generation with different vision of Islam and the patriarchal society within Egypt? (Yared, 2002) between 1919 and 1945 the Egyptian writers were tracking a path of increasing reason, individuality, and autonomy from the Ulema (Religious legislators). The Ulema preached and believed in narrow strain of Islam, that prevented the teaching of modern sciences, they rather focused on a rigid Islam that rejected fresh interpretations.

Qasim Amin, a Muslim, also said that because the ignorant ulema decided that "what few legislators had down was eternal truth; nobody had the right to oppose it...." Thus it is not surprising to read Taha Hussein's severe attacks on these doctors of religion in Egypt who used their power and influence to combat all 94 liberal thought, even before they prosecuted authors like him and Abd al-Raziq, and banned their books.

(Yared, 2002.p.64)

It is so important to comprehend the questions that are being raised within the Egyptian society while assuming an examination of the human predicament in the three novels of Cairo Trilogy and understanding the different important moments in the history of Islam and modernity, generational conflicts, and tradition that is essential to all the characters.

\subsection{Crossing Tough Boundaries}

Eventually the grown sons of the house man Alssayed reach to a time of revolution against the restrictions that are placed on them in earlier time of their life as illustrated in the first two novels of the Trilogy. Hence, in Sugar Street, the last novel, Kamal tries to be equal or excel his father in a time he is young, however, then persists to become a philosophy teacher meanwhile Yasin holds a government job and copies the behavior of his father of imperfection and betrayal and lack of moral responsibility. Kamal proves to be a good example of moral responsibility, despite the fact that he has rejected his faith. Yasin, who is portrayed as a hollow man, is a genuine example of immorality. Kamal's social circle is rather wide, the world that he lives in expanded with various components. However, the predicament that Kamal lives is 
rooted in sentiments and attitudes agitated in his young life stage and it subsists basically constant.... For instance, he goes against his father's wish and he selects to study philosophy and be a teacher. Kamal's passionate emotions and his childhood sentiments with philosophical, sometimes academic tendencies.... Yaseen had a great deal of attention not merely through the reflection of his sexually immoral behaviors and scandalous manner, but also through Kamal's abstract judgments of him. (Gassick 1991.p.58)

These two sons symbolize the modern, Western influence of the young generation, because both have taken a decision to go against their father who refers to tradition. Yasin ridicules his father as the latter talks to Fahmy about how their father is not tricky in having affairs with other women, but undergoes the rules and traditions of a Muslim Caliphate:

He gets drunk, and believe me, drinking is even better than eating. He has affairs and so did Muslim caliphs. Read about it in the ancient poems contained in Abu Tammam's anthology Diwan al-Hamasa or see its marginal glosses. Our father isn't doing anything sinful. (Mahfouz 1989.p.271)

In Palace Walk, Kamal establishes his life on the basis of reciting the Qur'ān and reading, because of his mother's impact. She is portrayed as the devout character and cornerstone of the household, and he is the youngest child and wants to emulate his father; however, he is the one son that opposes his father at the end of the novel. For instance, Kamal is the only child who oversteps the borders and insists on taking his mother, Amina, to AlHusayn's shrine and away from the house without consent of her patriarch husband. Kamal takes her on this small journey, the only step in her personal rebellion that ends up in her banishment from the house. Yasin her stepson, becomes pissed off by the punishment she underwent and questions his father, Al-Sayyid Ahmad, who is leading life that is marred with immoral affairs of his household:

You've got your religion and I've got mine. In other words, he was not inclined to impose his views blindly on other people. Although he could distinguish what really was good from what was bad, he was not willing to embrace every good thing. In that respect he was influenced by his sternly traditional nature, so much so that he considered his wife's visit to the shrine of alHusayn a crime deserving the gravest punishment he had meted out during his second marriage. (Mahfouz 1989.p.219)

\subsection{The Challenges of the New World Order}

Finally, in the last part of the novel Sugar Street, the newly introduced socialism as a movement away from tradition. The Egyptian culture is threatened with these new movements that are invading the world; hence, the Egyptian Muslim life is being challenged. The central subject for Mahfouz was the Egyptian individual that is exposed to such changes in the society which lead to the inevitable change in the Egyptian identity. Out of the existential predicament the modern Egyptian man like Kamal began to question the standing values and judgments as they observe the bleak present and the future that is to be marred with the corruption of by war, rebellions, and the foreign colony. The characters Kamal and his father are exponents in the trilogy, from the first book and continuing to the third; Kamal adores and worship his father in the same way he worships Allah; therefore, the type of relationship between the two is built on awe, respect, and fear "love". A love like that sounds to be more of a traditional value than of a real sentiment established on passion and love. This type of love was developed into harsh negative sentiments.

As for love, every member of the household loved the man (father) to the extent of worship, thus love for him seeped into the heart of the youngest (Kamal) due to the influence of the environment; it however, remained a gem hidden in a closed container of fear and terror. (El-Enany 1993.p.53)

Besides his predicament, Kamal feels his mother's predicament as she is banished away from the house. Such actions not only increased his grief but also instigate to question not only his father, but also the norms which implied to take a mother to holly shrine is wrong or guilt. As Amina comes back home, Kamal exclaims with ultimate excitement: "Today's dearer to me even than the procession with the holy shrine on the camel when pilgrims leave for Mecca" (Mahfouz 1989.p.233). On the other hand, Yasin is the son who matches and solaces himself in the reputation of his father's as a womanizer and drinking habit as he desecrates the memory of his while speaking to his brother Fahmy:

My father's prudent, a Muslim, and 1 loves women. It's as simple and clear as one plus one equals two. Perhaps I'm the one who most resembles him, because I'm a Muslim believer and love women, although I'm not 
too prudent. You yourself are a believer, prudent, and love women, but you base your acts on faith and prudence, while shying away from the third alternative: women.

(Mahfouz 1989.p.275)

Kamal is the best representative of the predicament of the Egyptian he maintained the sexual affairs with prostitutes and his sincere romantic love entirely is isolated. For him marriage is part of work and industry, and that love is no possible manner attributed to marriage. (El-Enany 1993.p. 64) Despite the fact that Kamal is the defining gate through which the reader can observe the lives of the characters in all three parts of the novel, he is too the individual that remains unmarried due to his understanding that marriage is not out of love.

More Significantly Kamal symbolizes the multiple changes that occur in Egypt and the intellectual world; he embodies science as well as ethics. He never back on his moral responsibility and he didn't exaggerate the religious issues. Kamal played double roles as a supporter the Ummah (Islamic nation) and individualistic effort. Kamal's predicament is not personal or an individual case yet it refers to the Egyptian atmosphere at large as it is disturbed, and in discrepancies due to the transformation and change by the effect of the European influence, for instance the inner struggle as narrated by Kamal, and the external misunderstanding among the other characters. According to El-Enany, In Sugar Street, Mahfouz identifies the two rival social philosophies through the two intellectual equals. In this matter both of the brothers Ahmad and Abd al-Mu'nimShawkat, Kamal's nephews. From the same family and the same university, yet they bear totally different have been more opinions; for Ahmad is an atheist socialist and Abd al-Mu'nim is a member of a Muslims brotherhood. It is as if Mahfouz, by making them so close, wanted to pinpoint the ultimate inevitability of a conflict between two powers which no social tie could avoid.” (El-Enany,1993. p.78).

\section{THE BETRAYAL IN THE THIEF AND THE DOGS}

In most of the literary works the readers can examine the state of predicament through the episodes of betrayal and treachery. Such actions are built on disdain abandonment, and denouncement. In this section the researcher would like to examine the character of Saeed Mohran a convicted who is in a deep predicament that is caused by the nearest people to him like his wife and his best friend. Hence, the natural reaction by any simple man is to retaliate and take revenge from those who betrayed. The novel is kind like a short story with a descriptive manner that is adopted from a real life story of a man who was released from jail and seeks revenge over the traitors. The events and the settings of the novel like the jail, cemetery and isolated café whereas Saeed used to hide himself from the police reflects the gloomy and the spooky atmosphere such acts contribute to the theme of existentialism. As we sense a tone of despair in the desperate protagonist Saeed who is bent to shed bloods of others.

The language is highly expressive and the vitality of the animal images is truly manifested in the novel, to emphasize the loose morality and the death of the humanitarian values. However, Mahfouz did not intend to write about the details of a real murderer's account, yet he made use of the character of Suliman to fitful his need; he made his mind to write a narrative of a character that is in a deep predicament. He selected Saeed's character with different aspects and dimensions that differentiate him from his real-life depiction AbdulmunimSulaiman. Such aspects may be falls under the classification of the cultural, religious and psychological dimensions, as exemplified in Saeed's reaction to Ra'uf 'Elwan, and the protagonist's relation with Sheikh 'Al1 al-Jinaid1 in respect to the religious dimension. Mahfouz made Saeed as a modern individual who tries to secure a place in the anarchic world. However, such attempts failed him due to his chaotic behavior and the overwhelming predicament that dominated his thoughts. As the reader can observe how Saeed bullets missed their target and led surplus chaos. Eventually the protagonist is considered as a tragic hero for all the standards of the tragic hero are applicable to his personae. His predicament sprouts from the urge for revenge. He declined from good to bad and his downfall is tragic, that arouses fear and pity in the reader. Overwhelmed by the feeling of betrayal and his poor judgement on circumstances, and, above all, by his excessive pride, or self-assumed superiority and selfconfidence he commits crimes. All these facts manifest themselves in his failure to satisfy his aspiration for revenge, as result brought about his tragic down fall.

When Saeed sees Sheikh Ali al-Jinaid1 immediately after he has just been set free from his jail, the omniscient narrator mentions: "The open space outside resounded with the braying of a donkey, which ended with throaty rattle like a sob. Somewhere a harsh voice was singing an ugly voice sang' where is my luck, where is my fortune" (Mahfouz.1984. p. 29). What the reader infers from this passage is that Saeed's fate is connected with the meaning of the word "luck" and his fortune is inevitably doomed to deteriorate sooner or later. The reader can assess the size of the traumatizing predicament on the protagonist Saeed 
through confusion mind, the choked emotions, and his perpetual quest for justice all instigated sympathetic responses from. The reader pities for him as he goes through hard times. However, Dr. FatmaMussa opines that the reader may not sympathy with Saeed due to the fact that the hero is represented as a detestable character by the novelist. She also adds: We do not mean here that the novelist is dragging the reader to feel sympathy with Saeed, the protagonist, ... Saeed Mahran is a detestable character... We might comprehend him as well as we may realize and understand the motivations that called upon his downfall, yet still, we cannot sympathize with him. Anyways Saeed is not depicted as totally detestable. He is open for love and humanistic in his feelings even in time of committing his first act of murder:

A useless effort you have made when you killed Sha'ban Hussain. Who are you Sha'ban, anyway? I don't know you and you don't know me. Do you have children? Did it ever cross your mind that one day you would be killed by someone you didn't know? Did it ever cross your mind that one day you will be needlessly killed just because NabawiyaSuliman has married 'ElashSidrah? And to be killed by mistake while 'Elalsh, Nabawiya or Ra'uf are still alive. And me, the murderer, doesn't understand anything. I wanted to solve part of the riddle, only to be confronted with a more mysterious one. (p. 114).

Saeed displayed a great deal of humanity through the profound love for Sana moreover, for the sake of his daughter he spared Nabawiya's life. In his ambition Saeed wishes to kill both Nabawiya and Elish for they both have spoiled his life. Moreover, the other goal to take Rauf Ilwan down for changing his principles and values then to escape abroad if possible. Yet Saeed is dragged into his predicament that is represented by his daughter Sana' who will be taking care of?

One more example of Saeed's sense of humanity is manifested in his behavior with Beyaza after he attacked him in the desert. He is able to put his hands on all his money, but chooses only ten pounds is enough for him, as he understands Beyaza's situation provide his family. Through the entire novel Saeed is portrayed as helpless to cope with his fate or even change it. Thus, he stands horrified, isolated and alone against the whole world in his attempt to restore his honor and pride.

\subsection{The Individual Agony}

Saeed is plunged in the past that is associated with his lost happiness and dreams, this happiness is not meant to last for more than a few moments, and turns into a hell very immediately after he remembers one of his enemies, that man who is the main source of pain and betrayal for Saeed; the entire situation grows as a nightmare that made of Saeed devil and hate-filled man whose utter goal is to hunt down and kill the traitors. He withstands almost incredible restlessness, boredom, self-punishment, despair, loneliness, and, but is never scared. With increasing irritation, he has got a shelter from the darkness in Noor's place. Saeed stroke a companionship with Mu'alimTarazan, with whom he walks along the Nile river. However, he feels left behind by his most close people. The predicament is culminated by the atmosphere of darkness and boring quietness. Saeed feels an increasing disillusionment by the effect of the traitors around him; The whole world is unjust" and brutal to him as he envisions it. Having reached a dangerous state of intoxication with self-pride, Saeed thinks himself superior to everyone: He really does not like loneliness. And he, among people, grows bigger and bigger, like a giant, practicing glove, leadership, and heroism. Without this he cannot enjoy life (p. 162).

In his stream of consciousness, he believes that he: .. always wished to destroy the whole world and turn it upside down, even when you were just a clown. Your victorious raids, on the palaces used to intoxicate your proud head. And Rauf's fake words which you believed, turned your head (p. 155-156).

No matter what the condition, Saeed decides to face whoever fails and betrayed him even if he will be alone in his plight, he set out vicious war against all his enemies, unworried by the warnings of Tarazan, who informed him that he cannot go against a significant man like Rauf, besides skipping Noor's warning that he is meant to lose in this game if he jeopardizes his life by fighting the whole society alone. Saeed has full confidence in himself and he tells Noor he can escape at any time he wants to: I will escape when I decide to escape, you'll see ...Don't you know who Saeed Mahran is (p. 140)?

But as the events unravel, Saeed Mahran is no abler to show love or other human feelings; he is overwhelmed with the idea of revenge on his enemies:

Is it possible that I could go through my life with no past and pretend to forget Nabawiya, Alish, and Ra'uf?If I could, I would be more relieved, more comfortable, and farther away from the gallows. But that's no way; life isn't worth living until I do what I have to do. I will never forget the past, for the simple reason that it is the present to me (p. 85).

\subsection{The Despair of the Hero}

Saeed the main character is not moved by the advices that are introduced to him by other friends, hence he is 
determined to hunt down the enemies that contributed to his misery and agony. The despair is clearly presented in his behavior as he persists on revenge.Saeed's crisis reached the climax as hearrives at the cemetery just across from Noor' s apartment. He now comprehends the reality of himself. For the first time: he is nothing, he is left alone after leaving Noor and Tarazan. Yet he is determined on doing what he must do, he chooses to stand and fight and welcomes death if there is no other way out. But "there is no other way but to surrender" to death. Therefore, he surrendered indifferently ... indifferently, His predicament is that he couldn't rehab in the society; he is unable to choosethe cultural neither materialistic nor the religion world as a means to find the way assert his place in the world that disdained him and betrayed him once.

\section{THE STRUGGLE FOR MEANING IN THE BEGGAR}

The last section of this chapter closes with one of the most agonizing theme of the novella The Beggar, in which the predicament of the modern man is well manifested in the personae of Omar, who gives the reader a sense of mystery and plight. Among his friends Omar is the only one who fell off the wagon. Due to his urge for a cure from an unknown sickness that stroke him in his middlelife period. The researcher in this section would like to shed the light on such inclination of the individual from the normal life of a poet and attorney. Due to being dragged into the dark human conditions the protagonist loses the sense of life. Hence, his most important people seized to mean anything to him. Therefore, such behavior directly contributes for the theme of the futility that is part of the broader term "existentialism".

Naguib Mahfouz's novella, al-Shahhad (The Beggar) recounts the events of the striving for sense of life, and the miserable anti-hero's struggles during the 1960s postrevolutionary Cairo that proved for certain people frustration and disappointment, an era of Gamal Abdel Nasser's regime. Mahfouz throughout the use of the character of Omar El Hamzawi the main character who displays an existential angst and plight of man to comprehend his position in life and matches his actions with consciousness. In the first part of the novel Omar has seen a doctor that he knows from his childhood. Omar mentions that he is sick as he "The Problem is very serious. I don't want to think, to move or to feel. My hope in coming here was to find some physical cause" he adds that "Everything is disintegrating and dying" (Mahfouz, 1986.p.12). Moreover, the doctor is puzzled as he figures out no disease is apparent in his diagnoses to Omar and advices him to practice some exercises, to release the tension moreover he should go on a diet and should also take a vacation from work. The previously socialist and poet, Omar abandons his passions to assumes the job of attorney, moreover in the earlier parts of the novel first the reader have an idea about his repression of his previous life, "Some of my physician colleagues have given up medicine for the sake of poetry" (p.16) the doctor informs him "The memory disturbed his consciousness like illomened weather". (p.16). His wife Zeinab a convert Muslim from Christianity met him in his youth. Zeinab Jeopardized everything by marrying him she is detached from her family, Hence, she adds more responsibility to Omar who is ready to collapse, ironically she knocked the door of the abandonment and entered the house of detachment due to the regression of her husband. Consequently, Omar doesn't stay committed to his moral responsibility which he claimed to preserve. With the passage of the time he is drenched into the engulfment of despair and constant search of meaning of life.

\subsection{The Detachment of the Hero}

Due to his unstoppable search of the cure for the unknown illness the main character Omar isolates and detaches himself from his family as well as the society. As a result, he physically and emotionally detached himself from his wife; however, Zeinab carries on supporting him and attempts to secure their family together in the midst of Omar's existential predicament. Omar eventually continues to slip away more and more. What culminates his predicament is the series of the sexual affairs that Omar assumes to hide behind in order to find a solace for his dire and boredom. For instance, Margaret, is one of the women in the novel that the protagonist Omar tries to engage in an affair with. She is a foreign singer, who caught his attention, yet she secretly disappears from Egypt; therefore, the Omar strikes an affair with woman dancer named Warda. In the meantime, the pregnant wife Zeinab suspects the behavior of her estranged husband until Omar at last goes to live with Warda and falls in love with her. Despite the fact that Warda leaves her dancing job to start her new life with him, things only lasted for a while, Omar's sickness dominates the love affair with Warda too and he is gain retreats into the predicament. Omar's tendency to cure his illness through the series of illicit relationships with prostitutes yielded no touchable results. However, the protagonist is relieved when being around the pyramids some dawn, he has undergone a fleeting pleasure of joy that brings him back to life once more and grants him peace, anyway his sickness prevails him again. By the end of his illicit relationships and desperate encounters Omar come back home with intense suffocation, hence on the individualistic level Naguib 
Mahfouz helps the reader to judge Omar the protagonist. The behavior and the relationships are the efforts of Omar to change or remove the dire have failed.

On the social level Omar is set in a comparison with his friends who survive the trauma of the revolution and the aftermath of it. Omar meets Othman Khalil his socialist colleague from his youth in his office. Just released from prison, his past time friend, Othman claims that he wasn't cooperated with the police when he was brutally interrogated regarding Omar in spite of the torture he was exposed to in prison. Hence the behavior of Othman proves a sensibility and balance, Othman is astonished that Omar has abandoned his socialist tendencies and the writing of poetry. Omar is overwhelmed with his predicament to the extent that he decides to live alone in the countryside, as even poetry seized to heal him. Spending more than one year there, Omar starts freaks out and hallucinates; moreover, he showed confusion towards Othman, who comes every once in a while to see him in his secluded place. Out of the fear and anxiety Omar thinks that the authorities are following Othman and he starts to fear. His images of hallucinations and reality entangled and meshed. In his daydreaming he imagines that the police arrest Othman and that he himself was injured by the police, as he feels his heart "beating in reality, not in a dream". Consequently, he envisions that he is "returning to the world". Omar's detachment from himself, family members and his friends leads to exaggerate his alienation that he has retreated into. Omar doesn't withstand the changes of in post-revolutionary Egypt. As a result, this leads him muddled feeling of reality and illusion that is reflected in a tight predicament.

\subsection{The Unstable Political Settings around the hero}

The conditions of the protagonist Omar are marred with the psychological torment; he led an ardent revolutionary youth. The political settings of Nasser's 1952 Revolution have left him crippled, killed his conscience. In his attempt to bridge the gap and attain redemption, he pays the price his family and his job and substitutes them with a streak of sexual affairs, which easily enlarged his predicament. And he is to have a separation from himself and the external settings and individuals.

Generally speaking, The Beggar, Omar looks hold handed in his routine life. The doctors are desperate; since Omar is sounds physically, but he is exhausted and consumed by the feeling of futility and anxiety. As an approach to run away, he directs his life in the reverse motion to expect a way out of the misery and anarchy of dark human conditions. Such a behavior doesn't seem to do anything to relieve him. The beggar in this novel is in a constant search for a genuine place in life or even a dead among the living, Omar El-Hamzaoui, is weaken inside, as a body which has neither desire nor natural impulses. A paralyzed beggar among the living, Omar reaches to point of predicament that pushes to calls upon death to grant him a feeling of living again and the chance that he belongs to the world.

The worth of The Beggar is not found in the superiority of science over art in the age of technology, which is a subject that is in many cases consumed. Rather, it lies in the fact that the novel presented the Arab audience to the antagonism between a life without horizons and nihilism, and the fact that society is exposed to change. The novel stresses the predicament of the individuals according to the fact that the mentioned belief is no more reasonable, being neither as full nor as positive as ameliorating dialogue would have it be. Meanwhile, the modern man of the 1960's has explored his irrelevance under the shadow of the nationalist State's cruel machinery. Not even free to be himself, he is forced into cop-out, censorship, the silencing of the conscience.

As it usually happens with Mahfouz, he has elegantly built the emotions and causes of everyday man to allow himself leave off his common and "normal" life, in the search of something that, at the start, not even he himself realize. Frustration and in despair is all he receives from his environments like family or work. The quest of "feeling alive" grows as an inner struggle with a predicament that concludes with the deliverance of being a "beggar".

In this paper, the researcher has selected to comment on the predicament of the modern man that is predominant theme in the four novels that are selected for the study. In the first section the text of the Midaq Alley offers exquisite example of men and woman predicament in their journey from the traditional society to a modern world of the colonizers. The characters in the novel hope to transfer from one place another one as they live in a predicament since the beginning of the journey and hang out with it for the midway through and ended it up with total failure.

The second section of this chapter argues that modern man is plighted and lives the predicament due to the collision of the antiquity and the modernity, the Cairo Trilogy provides examples of men with the predicament due to the generational clash. Moreover, in the third section the researcher entitles as the betrayal in which he argues about the middle aged man Saeed Mahran who feels a victim of the indifferent world and family and friends. The betrayal contributes to his predicament hence his only motive throughout the story is to get retaliation from those who stabbed him in the back. 
Finally, the Beggar is a short novella that recounts a man in his middle-life crisis, who deserts his job, family and poetry for the sake of getting cured; such behavior develops to a fact that is called the illness unknown. The mystery is a predicament for the protagonist Omar and the doctors who see no illness to be recognized. Hence Mahfouz has given us a genuine picture of the existential angst that the modern man in Egypt passed through in the same period of modernity. There is a huge sense of predicament and frustration on the account of the Egyptian man, and Naguib Mahfouz has successfully portrayed that in the selected novels of the study.

\section{CONCLUSION}

The researcher has selected to comment on the predicament of the modern man that is predominant theme in the four novels that are selected for the study. In the first section the text of the Midaq Alley offers exquisite example of men and woman predicament in their journey from the traditional society to a modern world of the colonizers. The characters in the novel hope to transfer from one place another one as they live in a predicament since the beginning of the journey and hang out with it for the midway through and ends it up with total failure.

The second section of this paper argues that modern man is plighted and lives the predicament due to the collision of the antiquity and the modernity, the Cairo Trilogy provides examples of men with the predicament due to the generational clash. Moreover, in the third section the researcher entitles as the betrayal in which he argues about the middle-aged man Saeed Mahran who feels a victim of the indifferent world and family and friends. The betrayal contributes to his predicament hence his only motive throughout the story is to get retaliation from those who stabbed him in the back.

Finally, the Beggar is a short novella that recounts a man in his middle-life crisis, who deserts his job, family and poetry for the sake of getting cured; such behavior develops to a fact that is called the illness unknown. The mystery is a predicament for the protagonist Omar and the doctors who see no illness to be recognized. Hence Mahfouz has given us a genuine picture of the existential angst that the modern man in Egypt passed through in the same period of modernity. There is a huge sense of predicament and frustration on the account of the Egyptian man, Naguib Mahfouz has successfully portrayed that in the selected novels of this paper.

\section{REFERENCES}

[1] Brugman, J, (1984.). An Introduction to the History of Modern Arabic Literature in Egypt. Leiden: Brill, Print.p.301

[2] Diiulio. P. A. (2007). Naguib Mahfouz: A Western and Eastern Cage of Female Entrapment. New York. Cambria press.pp.31,46,228, xxii.

[3] El-Enany, R. (1993) Naguib Mahfouz: The Pursuit of Meaning, London; New York:

[4] Routledge, pp.25, 61

[5] Lane. A. W, (1954). An Account of the Manner and customs of the Modern Egyptians. London, Everyman's library.p.341.

[6] Le Gassick. T. Ed. (1991). Critical perspectives on Naguib Mahfouz Washington: Three Continents Press.

[7] Mahfouz. N, (1947). Midaq Alley. Trans. Trevor Le Gassick. Washington: Three continents, 1966. Print. (First published in Arabic in 1947)

[8] Mahfouz. N, (1956). The Beggar Cairo: The American University in Cairo Press. P.52

[9] Mahfouz. N, (1989). Palace Walk: Cairo: The American University in Cairo Press.

[10] Mahfouz. N. (1986). The Beggar. Cairo, The American University in Cairo Press. p.52

[11] Mahfouz. N, (1986). The Beggar. Trans. By Kristen Walker Henry \&NarimanKhalesNaili al-Warraki. New York. The American University in Cairo Press

[12] Mahfouz. N, (1984). The Beggar; The Thief and the Dogs; Autumn Quail. Trans. Kristin Walker Henry and NarimanKhalesNaili Al-Warraki. New York: Anchor, 2000. Print.

[13] Walker. K. H\&Khales. N. N. al-Warraki, (1986). The Beggar. Trans. New York. The American University in Cairo Press

[14] Yared, S. N. (2002). Secularism and the Arab World. London: Saqi books. 